\title{
Cascade of Peritectic Reactions in the B-Fe-U System
}

\author{
M. Dias, P.A. Carvalho, A.P. Dias, M. Bohn, N. Franco, O. Tougait, H. Noël, and A.P. Gonçalves
}

(Submitted September 1, 2009; in revised form November 26, 2009)

\begin{abstract}
The solidification paths for $\mathrm{UFeB}_{4}, \mathrm{UFe}_{3} \mathrm{~B}_{2}$ and $\mathrm{UFe}_{4} \mathrm{~B}$, ternary compounds, situated along the $\mathrm{U}:(\mathrm{Fe}, \mathrm{B})=1: 5$ line in the $\mathrm{B}-\mathrm{Fe}-\mathrm{U}$ phase diagram, are proposed based on $\mathrm{x}$-ray powder diffraction measurements, differential thermal analysis, heating curves and scanning electron microscopy observations complemented with energy and wavelength dispersive $x$-ray spectroscopies. The compounds melt incongruently and are formed by peritectic reactions. The present work demonstrates the existence of a cascade of peritectic reactions along the $U:(\mathrm{Fe}, \mathrm{B})=1: 5$ composition line, establishes peritectic temperatures and proposes an isopleth diagram along this line.
\end{abstract}

Keywords microstructure, phase transformations, ternary alloy system

\section{Introduction}

Borides play an increasingly important role in present day engineering due to their high melting temperature as well as chemical and thermal stability. Moreover, ternary intermetallic borides of $\mathrm{AM}_{x} \mathrm{~B}_{y}$ type (with $\mathrm{M}$ a $d$-transition metal and $\mathrm{A}$ an actinide or rare earth) have attracted considerable interest due to a diversity of unusual physical characteristics, ${ }^{[1]}$ which extend from permanent magnetism with unusually large magnetic coercive fields, like in $\mathrm{SmCo}_{4} \mathrm{~B}^{[2]}$ and $\mathrm{SmNi}_{4} \mathrm{~B},{ }^{[3]}$ to unconventional magnetic ordering, as seen for $\mathrm{UNi}_{4} \mathrm{~B} .{ }^{[4]}$

Several compounds with atypical properties have been previously identified in U-Fe-X ternary systems (namely for $\mathrm{X}=\mathrm{Al}^{[5]}$ or $\mathrm{Sn}^{[6]}$ ), and interesting compounds can be also expected in the B-Fe-U system. However, data on this system is scarce and requires further investigation. Results on the B-Fe-U ternary diagram were previously reported by Valyovka and Kuzma, ${ }^{[7,8]}$ who identified the $\mathrm{UFeB}_{4}$ and $\mathrm{UFe}_{3} \mathrm{~B}_{2}$ compounds. Recent systematic studies on the isothermal section at $950{ }^{\circ} \mathrm{C}$ revealed the existence of three

M. Dias, Departamento de Química, Instituto Tecnológico e Nuclear/ CFMC-UL, P-2686-953 Sacavém, Portugal and Departamento de Engenharia de Materiais, Instituto Superior Técnico, Av Rovisco Pais, 1049-001 Lisboa, Portugal; A.P. Gonçalves, Departamento de Química, Instituto Tecnológico e Nuclear/CFMC-UL, P-2686-953 Sacavém, Portugal; P.A. Carvalho, Departamento de Engenharia de Materiais, Instituto Superior Técnico, Av Rovisco Pais, 1049-001 Lisboa, Portugal; A.P. Dias, Departamento de Engenharia Química e Biológica, Instituto Superior Técnico, Av. Rovisco Pais, 1049-001 Lisboa, Portugal; M. Bohn, Departement DRO/Geosciences Marines, Ifremer Centre de Brest, B.P. 70-29280 Plouzane, France; N. Franco, Departamento de Física, Instituto Tecnológico e Nuclear/CFN-UL, P-2686-953 Sacavém, Portugal; O. Tougait and H. Noël, Laboratoire de Chimie du Solide et Inorganique Moléculaire, UMR CNRS 6511, Université de Rennes 1, Avenue de Général Leclerc, 35042 Rennes, France. Contact e-mail: apg@itn.pt. other ternary compounds: (i) $\mathrm{UFe}_{4} \mathrm{~B}$, with a hexagonal structure closely related to the $\mathrm{CeCo}_{4} \mathrm{~B}$-type structure $\left(a=0.4932(1) \mathrm{nm}\right.$ and $\left.c=0.7037(2) \mathrm{nm}^{[9]}\right)$; (ii) $\mathrm{U}_{2} \mathrm{Fe}_{21} \mathrm{~B}_{6}$, with a cubic $\mathrm{Cr}_{23} \mathrm{C}_{6}$-type structure $\left(a=1.0766(4) \mathrm{nm}^{[9]}\right)$ and (iii) $\mathrm{UFe}_{2} \mathrm{~B}_{6}$ with a $\mathrm{CeCr}_{2} \mathrm{~B}_{6}$-type structure $(a=0.31401 \mathrm{~nm}$, $b=0.61842$ and $c=0.82218 \mathrm{~nm}^{[10]}$ ).

The present study aims to analyze the solidification path and identify the formation reactions of ternary compounds with an atomic $\mathrm{U}:(\mathrm{Fe}, \mathrm{B})$ ratio of $1: 5$, i.e., $\mathrm{UFeB}_{4}, \mathrm{UFe}_{3} \mathrm{~B}_{2}$ and $\mathrm{UFe}_{4} \mathrm{~B}$. This knowledge is required to establish adequate processes for pure compounds synthesis, necessary in turn to their subsequent physical properties characterization. Powder (XRD) and high temperature (HTXRD) x-ray diffraction, scanning electron microscopy (SEM), complemented with energy and wavelength dispersive $\mathrm{x}$-ray spectroscopies (respectively, EDS and WDS), differential thermal analysis (DTA) and heating curves obtained from an induction furnace (IF) have been used in this study.

\section{Experimental}

Over 60 alloys with general xU:yFe:zB compositions were prepared by melting together the elements (purity $>$ 99.9 at.\%) in an arc furnace equipped with a cold crucible under an argon atmosphere. The surface of uranium pieces was deoxidized in diluted nitric acid prior to melting. In order to ensure homogeneity, the samples were melted at least three times before quenching to room temperature. No losses higher than 1 wt.\% were observed. The high cooling rate of the solidification process enabled the solidification path of the alloys to be followed under non-equilibrium conditions. Subsequent heat treatments at $950{ }^{\circ} \mathrm{C}$ allowed inferring the transitions leading to equilibrium.

$\mathrm{X}$-ray powder diffractograms of the as-cast samples were collected at room temperature with monochromatic $\mathrm{Cu} \mathrm{K}_{\alpha}$ radiation using an Inel CPS 120 diffractometer, equipped with a position-sensitive detector covering $120^{\circ}$ in $2 \theta$ with a resolution of $0.03^{\circ}$, and a Philips X'Pert diffractometer with a $2 \theta$-step size of $0.02^{\circ}$ from 10 to $70^{\circ}$. The Powder Cell software package ${ }^{[11]}$ was used to simulate diffractograms for comparison with experimental data. 
The microstructures were observed in secondary and backscattered electron modes (respectively, SE and BSE) on polished and etched surfaces using a JEOL JSM-7001F field emission gun scanning electron microscope equipped for EDS. This spectroscopy technique was primarily used for efficient x-ray map collection, whereas (quantitative) analysis was carried out with a Cameca SX100 electron microprobe micro-analyzer (EPMA) equipped with five wavelength dispersive spectrometers. In the present study, a multilayer Mo- $\mathrm{B}_{4} \mathrm{C}$ crystal with a large interplanar distance $(2 d=210.36 \mathrm{~nm})$ was used to detect boron, a lithium fluoride (LIF) crystal $(2 d=4.03 \mathrm{~nm})$ was used to detect uranium and a pentaerythrirol (PET) crystal $(2 d=8.75 \mathrm{~nm})$ was used to detect iron. The elements were analyzed simultaneously using $\mathrm{BK} \alpha, \mathrm{UM} \beta$ and $\mathrm{FeK} \alpha$ transitions, for an acceleration voltage of $15 \mathrm{kV}$, a beam current of $20 \mathrm{nA}$, and using $\mathrm{CeB}_{6}, \mathrm{UC}$ and $\alpha-\mathrm{Fe}$ as standards. Typical beam sizes were $\sim 100 \mathrm{~nm}$ and the interaction volume was $\sim 1 \mu \mathrm{m}^{3}$. The X-phi correction software package was used to calculate the relative element proportions. ${ }^{[12]}$ Quantitative analyses were performed in 13 representative alloys with nominal compositions close to or on the $\mathrm{U}:(\mathrm{Fe}, \mathrm{B})=1: 5$ line. Each phase was analyzed in more than 6 randomly selected points.

DTA measurements were carried out for 6 alloys up to $1600{ }^{\circ} \mathrm{C}$, using a Setaram DTA Labsys and employing open alumina crucibles and a permanent argon flow. Sample masses of $60-120 \mathrm{mg}$ were used on the experiments. The optimized heating and cooling rates for clear peak evidence vs acquisition efficiency were 5 and $10{ }^{\circ} \mathrm{C} / \mathrm{min}$. The difference in temperature measured for the same transformations at different cooling rates indicated that the undercooling/overheating $(\Delta T)$ values were below $5{ }^{\circ} \mathrm{C}$. DTA curves were normalized for mass and the transition temperatures were determined from the derivative curves. Additionally, heating curves up to $2000{ }^{\circ} \mathrm{C}$ were obtained at $10 \mathrm{~W} / \mathrm{min}$ in an induction furnace (IF) coupled with an optical pyrometer. Due to the high cooling rates used to process the alloys in the arc furnace, the original microstructures were distinct from the microstructures resulting from the heating/cooling cycles. For this reason the temperatures of the transitions observed in the as-cast microstructures were essentially accessed from the heating stages of the cycles.

HTXRD was used to identify the phase transformations detected by DTA results up to $980{ }^{\circ} \mathrm{C} . \mathrm{Cu} \mathrm{K} \alpha$ line was collimated with a Gobël mirror and a divergent slit of $1 \times 10 \mathrm{~mm}^{2}$, and filtered with a Ge(111) two-crystal monochromator. X-ray diffractograms of as-cast $\mathrm{U}: 4 \mathrm{Fe}: \mathrm{B}$ samples were collected on polished surfaces with typical $11 \times 9 \mathrm{~mm}^{2}$ areas. The measurements were made continuously during heating at a rate of $5{ }^{\circ} \mathrm{C} / \mathrm{min}$ under a vacuum pressure of $10^{-4}$ mbar using a MBraun ASA 50M PSD detector with an acquisition time of $12 \mathrm{~s}$ in the $41-48^{\circ} 2 \theta$ range. The temperature was measured with a thermocouple welded to the sample surface and checked with a microoptical pyrometer (PYRO 95). Above $700{ }^{\circ} \mathrm{C}$, the temperature deviations detected with the pyrometer were below $1 \%$.

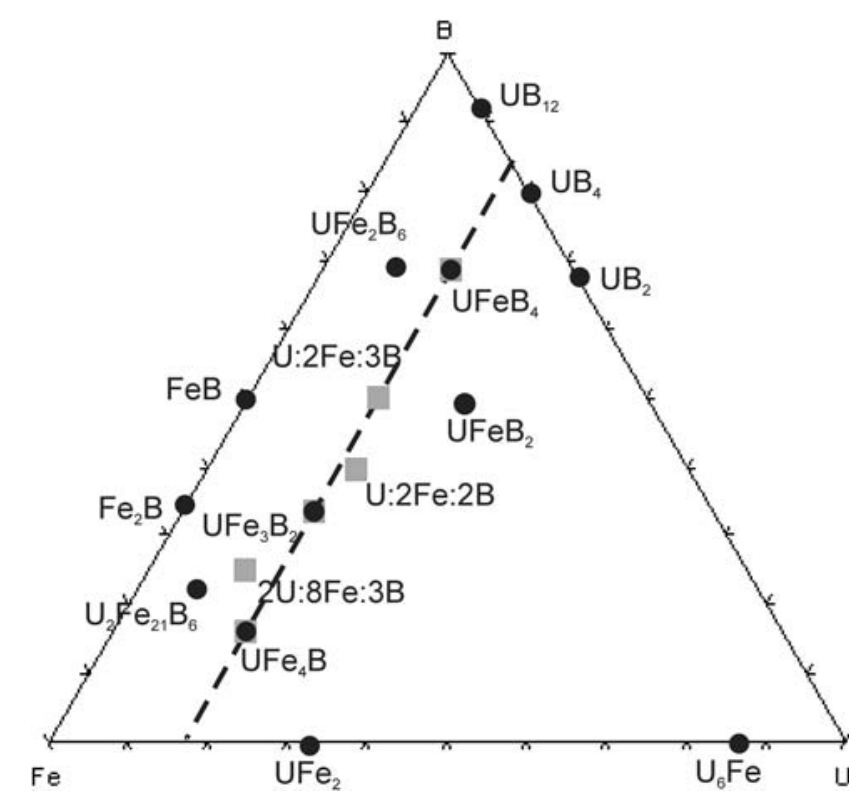

Fig. 1 Representation of binary and ternary compounds reported for the B-Fe-U system (black circles) and composition of the six alloys presented in this work (grey squares)

The results presented below are focused on the U:Fe:4B, $\mathrm{U}: 2 \mathrm{Fe}: 3 \mathrm{~B}, \mathrm{U}: 2 \mathrm{Fe}: 2 \mathrm{~B}, \mathrm{U}: 3 \mathrm{Fe}: 2 \mathrm{~B}, 2 \mathrm{U}: 8 \mathrm{Fe}: 3 \mathrm{~B}$ and $\mathrm{U}: 4 \mathrm{Fe}: \mathrm{B}^{\prime}$ alloys (Fig. 1) where the phase transformations are best evidenced.

\section{Results and Discussion}

Binary and ternary compounds previously identified in the B-Fe-U system are plotted as black circles in the ternary diagram shown in Fig. 1, where the composition of the representative alloys is shown as gray squares. The complex microstructures obtained for the alloys with compositions corresponding to the compounds stoichiometry, that is $\mathrm{U}: \mathrm{Fe}: 4 \mathrm{~B}, \mathrm{U}: 3 \mathrm{Fe}: 2 \mathrm{~B}$ and $\mathrm{U}: 4 \mathrm{Fe}: \mathrm{B}$, show they do not melt congruently.

\subsection{XRD Results}

Figures 2 and 3 present the XRD results obtained for the $\mathrm{U}: \mathrm{Fe}: 4 \mathrm{~B}$ and U:3Fe:2B alloys, respectively. Although the diffractogram of the as-cast $\mathrm{U}: \mathrm{Fe}: 4 \mathrm{~B}$ alloy evidences a significant presence of $\mathrm{UB}_{4}$, the major peaks correspond to $\mathrm{UFeB}_{4}$. This indicates that the $\mathrm{UFeB}_{4}$ liquidus field is close to its nominal composition. The diffractogram of the $\mathrm{U}: 3 \mathrm{Fe}: 2 \mathrm{~B}$ alloy exhibits $\mathrm{UFe}_{3} \mathrm{~B}_{2}$ as the predominant phase. However, $\mathrm{UFeB}_{4}$ and $\mathrm{UFe}_{2}$ are also major phases and there is evidence of minor proportions of $\mathrm{UFe}_{4} \mathrm{~B}$ (peak at $32.5^{\circ}$ ) and $\alpha-F e$ (peak at $44.7^{\circ}$ ). The U:4Fe:B alloy exhibited a diffractogram similar to the $\mathrm{U}: 3 \mathrm{Fe}: 2 \mathrm{~B}$ one, evidencing however a less significant presence of $\mathrm{UFeB}_{4}$ and a slight increase of $\mathrm{UFe}_{4} \mathrm{~B}$ and $\alpha$-Fe. 


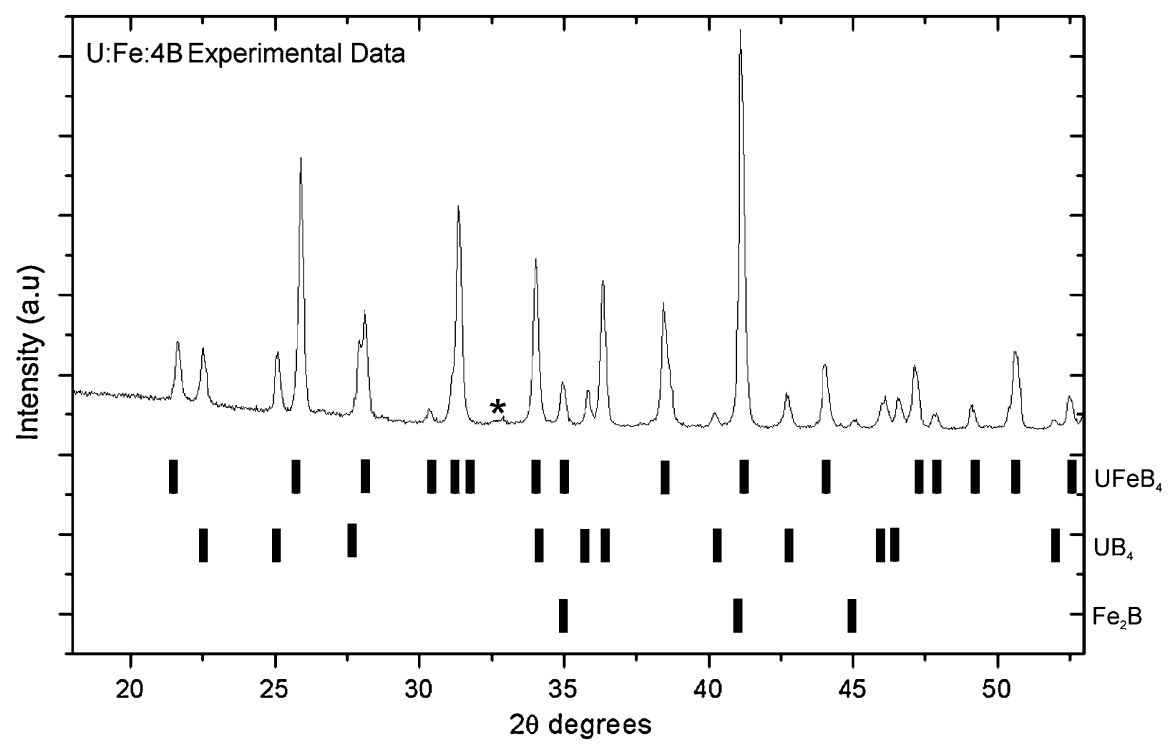

Fig. 2 Experimental x-ray diffractogram of the $U: F e: 4 B$ alloy with indication of peak localization for the phases present $\left(U_{F e} B_{4}, U B_{4}\right.$ and $\mathrm{Fe}_{2} \mathrm{~B}$ compounds). The U:Fe:4B alloy presents major peaks of $\mathrm{UFeB}_{4}$ and minor peaks of $\mathrm{UB}_{4}$ and $\mathrm{Fe}_{2} \mathrm{~B}$. The star indicates an incipient peak of $\mathrm{UB}_{2}$

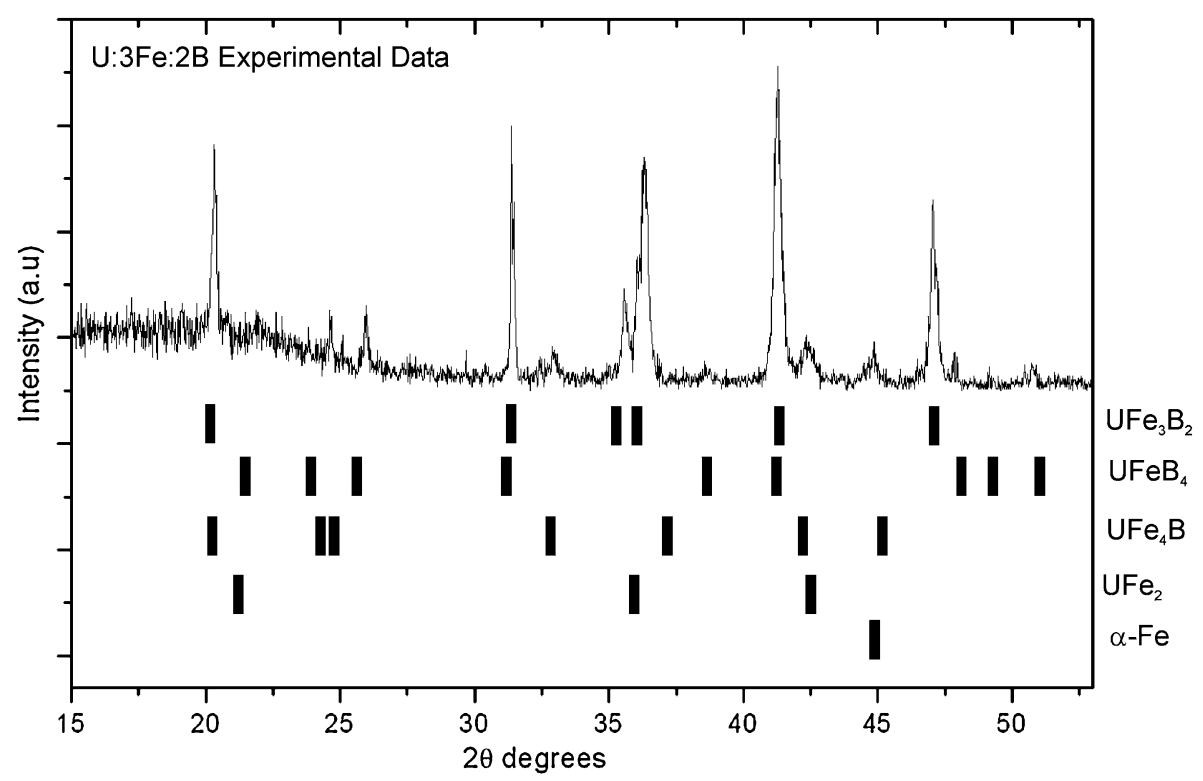

Fig. 3 Experimental $x$-ray diffractogram of the U:3Fe:2B alloy with indication of peak localization for the phases present $\left(U F e_{3} B_{2}\right.$, $\mathrm{UFeB}_{4}, \mathrm{UFe}_{2}, \mathrm{UFe}_{4} \mathrm{~B}$, compounds and $\alpha-\mathrm{Fe}$ ). The alloy presents major peaks of $\mathrm{UFe}_{3} \mathrm{~B}_{2}$, overlapping with $\mathrm{UFeB}_{4}$ ones, and minor peaks of $\mathrm{UFe}_{4} \mathrm{~B}, \mathrm{UFe}_{2}$ and $\alpha-\mathrm{Fe}$

\subsection{Microstructural Characterization}

Typical microstructures of alloys with nominal composition corresponding to the compounds stoichiometry are presented in Fig. 4. The phase labeling, average composition (AV) and composition standard deviation (SD) are presented in Table 1 .

According to the SEM images, the $\mathrm{U}: \mathrm{Fe}: 4 \mathrm{~B}$ as-cast microstructure presents three differentiated regions, designated as A, B and G (Fig. 4a1 and a2), which, in agreement with the EPMA and EDS results (Table 1), correspond to $\mathrm{UB}_{4}, \mathrm{UFeB}_{4}$ and $\mathrm{Fe}_{2} \mathrm{~B}$ respectively. The dendritic morphology of $\mathrm{UB}_{4}$ (bright phase in Fig. 4a1), indicates that crystallization started with this phase. The $\mathrm{UB}_{4}$ dendrites evidence surrounding of $\mathrm{UFeB}_{4}$ phase (see Fig. 4a) and suggest a partial replacement during the subsequent solidification by a peritectic reaction, which implies a 

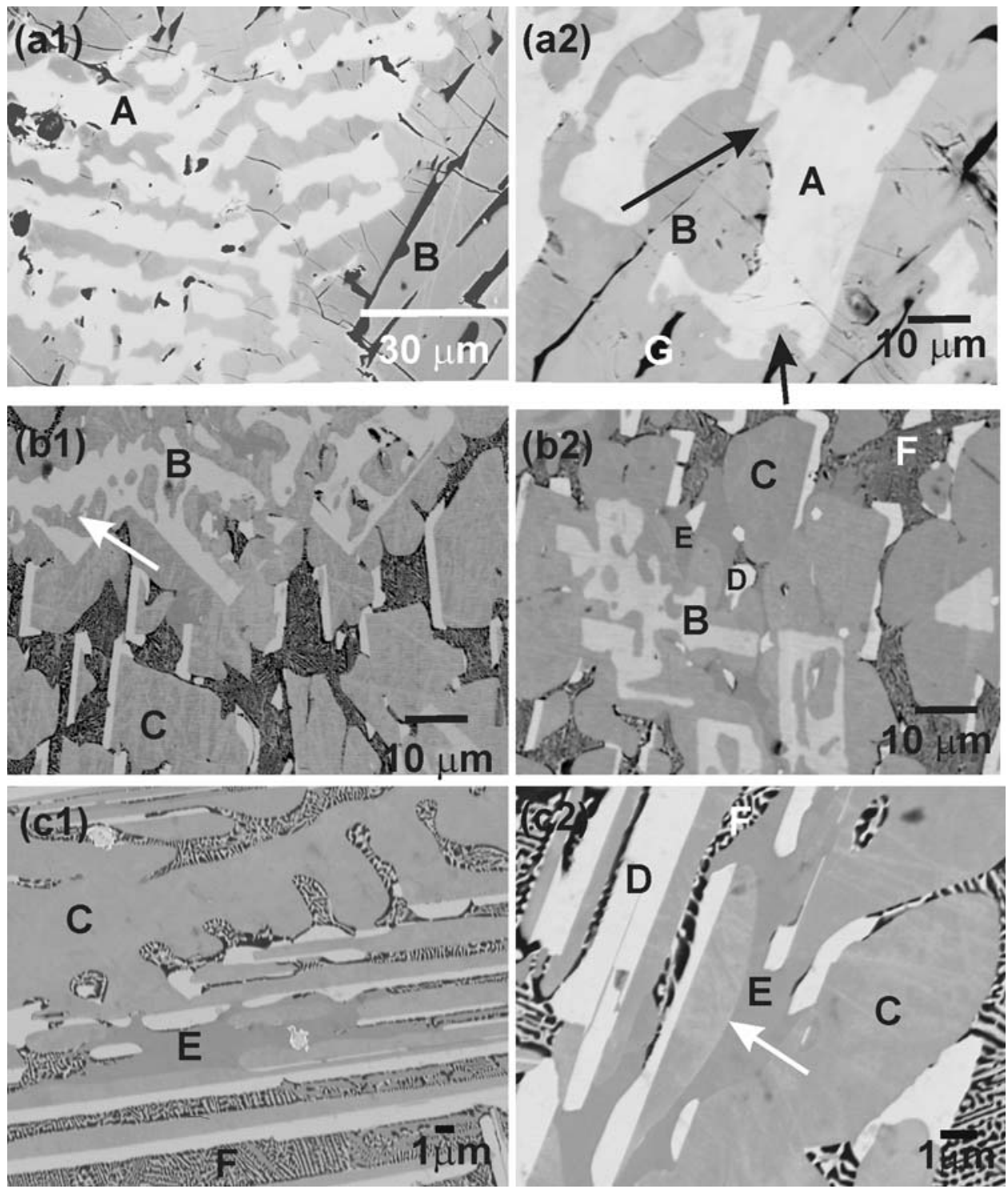

Fig. 4 BSE images representing the typical microstructure at different scales of U:Fe:4B (a1 and a2), U:3Fe:2B (b1 and b2) and $\mathrm{U}: 4 \mathrm{Fe}: \mathrm{B}(\mathrm{c} 1$ and $\mathrm{c} 2$ ) alloys. The phase labelling is given in Table 1. The arrows point to phase consumption in peritectic reactions

Table 1 Region labeling, electron-probe microanalysis results and corresponding phase(s)

\begin{tabular}{|c|c|c|c|c|c|c|c|c|}
\hline \multirow[b]{2}{*}{ Label } & \multicolumn{2}{|c|}{$\mathrm{U}$, at.\% } & \multicolumn{2}{|c|}{$\mathrm{Fe}$, at. $\%$} & \multicolumn{2}{|c|}{ B, at.\% } & \multirow[b]{2}{*}{ Elemental proportion } & \multirow[b]{2}{*}{ Phase(s) } \\
\hline & $\mathbf{A V}$ & SD & $\mathbf{A V}$ & SD & AV & SD & & \\
\hline A & $\ldots$ & $\ldots$ & $\ldots$ & $\ldots$ & $\ldots$ & $\ldots$ & $\ldots$ & $\mathrm{UB}_{4}$ \\
\hline B & 15.37 & 0.10 & 16.57 & 0.22 & 68.05 & 0.30 & $\mathrm{U}_{1.00} \mathrm{Fe}_{1.07(8)} \mathrm{B}_{4.42(6)}$ & $\mathrm{UFeB}_{4}$ \\
\hline $\mathrm{C}$ & 15.96 & 0.09 & 50.18 & 0.24 & 33.85 & 0.21 & $\mathrm{U}_{1.00} \mathrm{Fe}_{3.14(4)} \mathrm{B}_{2.12(0)}$ & $\mathrm{UFe}_{3} \mathrm{~B}_{2}$ \\
\hline $\mathrm{D}$ & 33.81 & 0.33 & 66.76 & 1.03 & 0.00 & 0.00 & $\mathrm{U}_{1.00} \mathrm{Fe}_{1.97(4)}$ & $\mathrm{UFe}_{2}$ \\
\hline $\mathrm{E}$ & 13.28 & 0.23 & 71.46 & 0.51 & 15.26 & 0.66 & $\mathrm{U}_{1.00} \mathrm{Fe}_{5.37(9)} \mathrm{B}_{1.14(8)}$ & $\mathrm{UFe}_{4} \mathrm{~B}$ \\
\hline $\mathrm{F}$ & $\ldots$ & $\ldots$ & $\ldots$ & $\ldots$ & $\ldots$ & $\ldots$ & $\ldots$ & $\mathrm{UFe}_{4} \mathrm{~B}+\mathrm{UFe}_{2}+\alpha-\mathrm{Fe}$ \\
\hline G & $\ldots$ & $\ldots$ & $\ldots$ & $\ldots$ & $\ldots$ & $\ldots$ & $\ldots$ & $\mathrm{Fe}_{2} \mathrm{~B}$ \\
\hline $\mathrm{H}$ & $\ldots$ & $\ldots$ & $\ldots$ & $\ldots$ & $\ldots$ & $\ldots$ & $\ldots$ & $\mathrm{UFe}_{3} \mathrm{~B}_{2}+\mathrm{UFe}_{2}$ \\
\hline I & $\ldots$ & $\ldots$ & $\ldots$ & $\ldots$ & $\ldots$ & $\ldots$ & $\ldots$ & $\mathrm{UFe}_{2}+\mathrm{Fe}$ \\
\hline
\end{tabular}


boundary reaction between the $\mathrm{UB}_{4}$ and $\mathrm{UFeB}_{4}$ liquid fields of the type:

$$
\mathrm{L}_{1}: \mathrm{L}+\mathrm{UB}_{4} \rightarrow \mathrm{UFeB}_{4}
$$

The microstructure of the U:3Fe:2B alloy, shown in Fig. 4 (b1) and (b2), presents a bright dendritic phase of primary crystallization (region B), a surrounding darker phase (region C), bright plates (region D), elongated patches of a darker $\mathrm{E}$ phase surrounding regions $\mathrm{C}$ and $\mathrm{D}$, and an interdendritic ternary eutectic (region $\mathrm{F}$ ). EPMA results indicate that phases $\mathrm{B}, \mathrm{C}, \mathrm{D}$, and $\mathrm{E}$ correspond respectively to $\mathrm{UFeB}_{4}, \mathrm{UFe}_{3} \mathrm{~B}_{2}$, $\mathrm{UFe}_{2}$ and $\mathrm{UFeB}_{4}$ (Table 1). The dendrite morphology of $\mathrm{UFeB}_{4}$ phase suggest that this phase was partly consumed in a peritectic reaction during the subsequent solidification of $\mathrm{UFe}_{3} \mathrm{~B}_{2}$, implying a boundary reaction between the $\mathrm{UFeB}_{4}$ and $\mathrm{UFe}_{3} \mathrm{~B}_{2}$ liquid fields of the type:

$$
\mathrm{L}_{2}: \mathrm{L}+\mathrm{UFeB}_{4} \rightarrow \mathrm{UFe}_{3} \mathrm{~B}_{2}
$$

Solidification was followed by formation of $\mathrm{UFe}_{4} \mathrm{~B}$ through an also apparent peritectic reaction, which implies a boundary reaction between the $\mathrm{UFe}_{3} \mathrm{~B}_{2}$ and $\mathrm{UFe}_{4} \mathrm{~B}$ liquid fields of the type:

$$
\mathrm{L}_{3}: \mathrm{L}+\mathrm{UFe}_{3} \mathrm{~B}_{2} \rightarrow \mathrm{UFe}_{4} \mathrm{~B}
$$

with an ensuing crystallization of $\mathrm{UFe}_{2}$ (regions D). The crystallization of this binary congruent compound from the ternary composition liquid implies a boundary reaction between the $\mathrm{UFe}_{3} \mathrm{~B}_{2}$ and $\mathrm{UFe}_{2}$ liquidus fields of the type:

$$
\mathrm{L}_{4}: \mathrm{L} \rightarrow \mathrm{UFe}_{3} \mathrm{~B}_{2}+\mathrm{UFe}_{2}
$$

and solidification ended at the ternary eutectic reaction (region F):

$$
\mathrm{E}_{1}: \mathrm{L} \rightarrow \mathrm{UFe}_{4} \mathrm{~B}+\mathrm{UFe}_{2}+\gamma-\mathrm{Fe}
$$

The microstructure of the U:4Fe:B alloy, shown in Fig. 4(c1) and (c2) is similar to the previous one, with the absence of $\mathrm{L}_{1}$ reaction product and increased evidence of reactions $\mathrm{L}_{3}, \mathrm{~L}_{4}$ and $\mathrm{E}_{1}$, in agreement with the XRD results. The consumption of $\mathrm{UFe}_{3} \mathrm{~B}_{2}$ during formation of the peritectic $\mathrm{UFe}_{4} \mathrm{~B}$ is suggested from the examination of Fig. 4(c1) and (c2).

A close inspection of the alloys microstructures confirmed the eutectic nature of $\mathrm{L}_{4}$ and $\mathrm{E}_{1}$ reactions. As shown in Fig. 5(a), in alloys with $\mathrm{U}:(\mathrm{Fe}, \mathrm{B})>1: 5$, such as $\mathrm{U}: 2 \mathrm{Fe}: 2 \mathrm{~B}$, the $\mathrm{L}_{4}$ reaction produces a lamellar binary mixture of $\mathrm{UFe}_{3} \mathrm{~B}_{2}$ and $\mathrm{UFe}_{2}$. As shown in Fig. 5(b), region $\mathrm{F}$ is a ternary eutectic constituted by an Fe-rich phase (dark in BSE imaging and which according to the XRD results is $\gamma-\mathrm{Fe}$ ), $\mathrm{UFe}_{4} \mathrm{~B}$ (these eutectic lamellas stem from the surrounding $\mathrm{UFe}_{4} \mathrm{~B}$ patches with similar contrast) and $\mathrm{UFe}_{2}$ (these bright eutectic lamellas stem from the surrounding $\mathrm{UFe}_{2}$ plates with similar contrast).
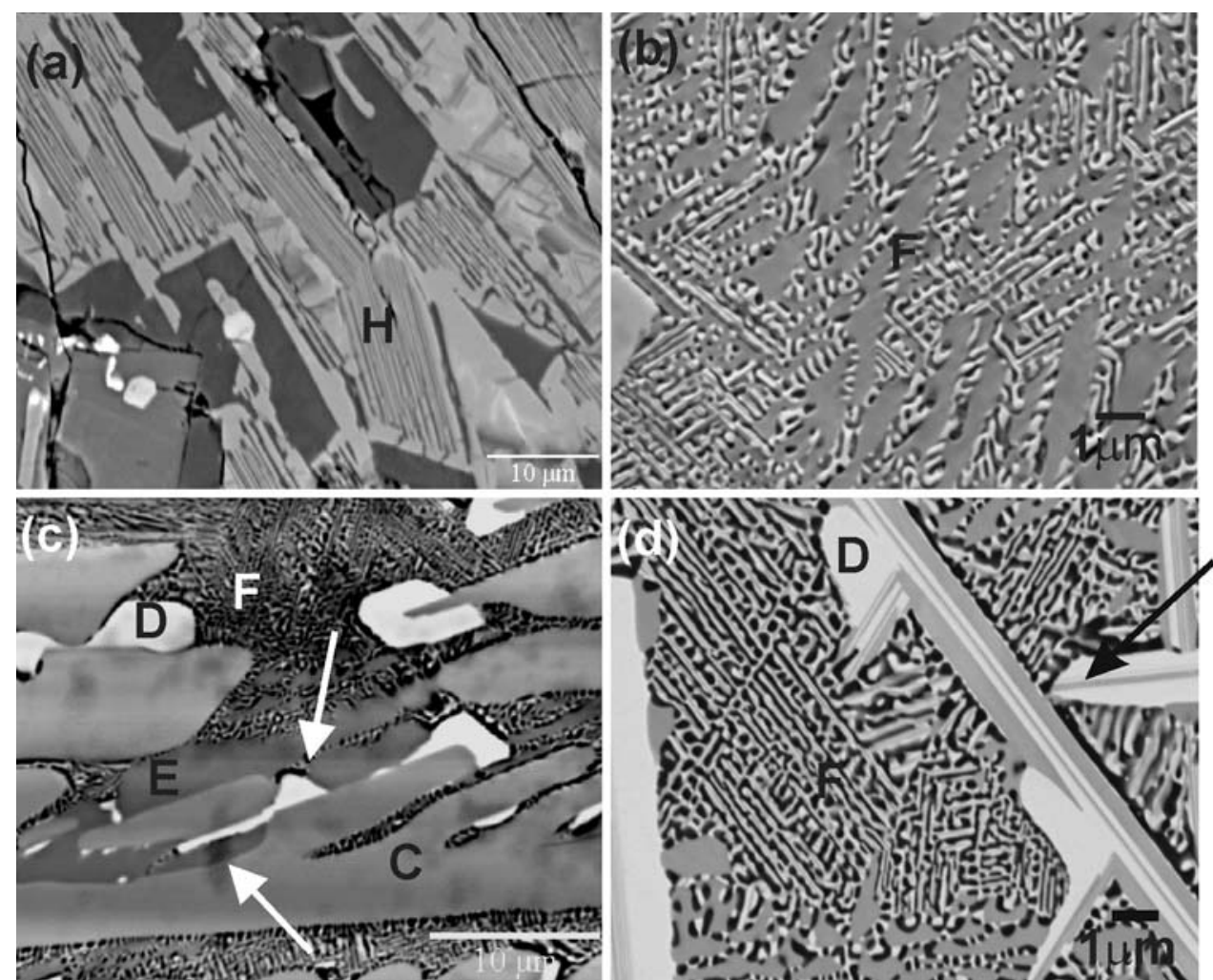

Fig. 5 (a) Eutectic reaction $\mathrm{L}_{4}$ (region $\mathrm{H}$ ) in the U:2Fe:2B alloy. (b) Ternary eutectic $\left(\mathrm{E}_{1}\right)$ in the U:2Fe:3B alloy. (c) Consumption of both $\mathrm{UFe}_{3} \mathrm{~B}_{2}$ and $\mathrm{UFe}_{2}$ in association with $\mathrm{UFe}_{4} \mathrm{~B}$ formation $\left(\mathrm{P}_{1}\right)$ in the $2 \mathrm{U}: 8 \mathrm{Fe}: 3 \mathrm{~B}$ alloy. The arrows point to consumed recesses of regions $\mathrm{C}$ and $\mathrm{D}$. (d) Lamellar $\mathrm{UFe}_{4} \mathrm{~B}+\mathrm{UFe}_{2}$ eutectic mixture (L5) in the $\mathrm{U}: 4 \mathrm{Fe}: \mathrm{B}$ alloy 
Figure 4(b2) and (c2) evidence a competition between reactions $\mathrm{L}_{3}$ and $\mathrm{L}_{4}$, i.e., while the $\mathrm{U}: 3 \mathrm{Fe}: 2 \mathrm{~B}$ microstructure in (b2) shows that $\mathrm{UFe}_{4} \mathrm{~B}$ formed around $\mathrm{UFe}_{3} \mathrm{~B}_{2}$ before and competing with $\mathrm{UFe}_{2}$; the $\mathrm{U}: 4 \mathrm{Fe}: \mathrm{B}$ microstructure in (c2) shows that $\mathrm{UFe}_{2}$ is formed around $\mathrm{UFe}_{3} \mathrm{~B}_{2}$ before $\mathrm{UFe}_{4} \mathrm{~B}$. These results indicate that $\mathrm{L}_{3}$ and $\mathrm{L}_{4}$ converge at or near the $\mathrm{U} /(\mathrm{Fe}, \mathrm{B})=1: 5$ line, where the two alloys lie. The detected general prevalence of $\mathrm{L}_{4}$ over $\mathrm{L}_{3}$ can be justified by the fact that local composition variations tend to induce a liquid composition slide down towards the $\mathrm{L}_{4}$ eutectic valley. On the other hand, some microstructures revealed that formation of $\mathrm{UFe}_{4} \mathrm{~B}$ (region E) involved consumption of both $\mathrm{UFe}_{3} \mathrm{~B}_{2}(\mathrm{C})$ and $\mathrm{UFe}_{2}$ (D) (Fig. 5c). Therefore, the phase transformation at the $\mathrm{L}_{3}$ and $\mathrm{L}_{4}$ convergence point corresponds to a ternary peritectic reaction of the type:

$$
\mathrm{P}_{1}: \mathrm{L}+\mathrm{UFe}_{3} \mathrm{~B}_{2}+\mathrm{UFe}_{2} \rightarrow \mathrm{UFe}_{4} \mathrm{~B}
$$

The transition between the invariant reactions, $\mathrm{P}_{1}$ and $\mathrm{E}_{1}$, occurs through the formation of a lamellar binary eutectic (evidenced in Fig. 5d), implying:

$$
\mathrm{L}_{5}: \mathrm{L} \rightarrow \mathrm{UFe}_{4} \mathrm{~B}+\mathrm{UFe}_{2}
$$

The solidification sequence presented above establishes a cascade of peritectic reactions along the $\mathrm{U}:(\mathrm{Fe}, \mathrm{B})=1: 5$ line:

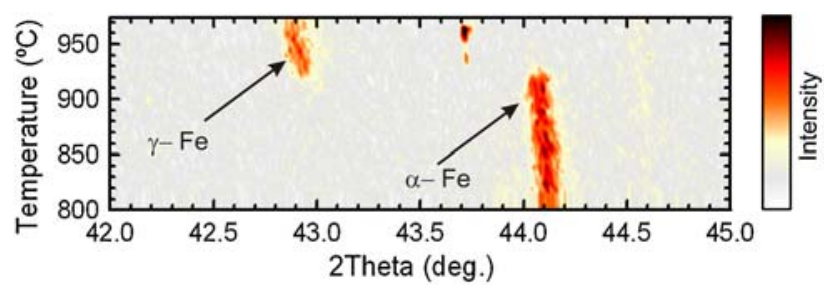

Fig. 6 HTXRD results of $\alpha$-Fe to $\gamma$-Fe transformation

Table 2 Temperatures extracted from the DTA signals and IF results and relation with the transformations

\begin{tabular}{|c|c|c|c|}
\hline Sample composition & Reactions & Temperature, ${ }^{\circ} \mathrm{C}$ & Technique \\
\hline \multirow[t]{9}{*}{$\mathrm{U}: 4 \mathrm{Fe}: \mathrm{B}$} & $\begin{array}{l}\text { - Allotropic transformation } \\
\alpha-\mathrm{Fe} \rightarrow \gamma-\mathrm{Fe}\end{array}$ & 940 & DTA \\
\hline & - Ternary eutectic $\left(\mathrm{E}_{1}\right)$ & 980 & DTA \\
\hline & $\mathrm{UFe}_{4} \mathrm{~B}+\mathrm{UFe}_{2}+\gamma-\mathrm{Fe} \rightarrow \mathrm{L}$ & & \\
\hline & - Boundary reaction $\left(\mathrm{L}_{5}\right)$ & 1020 & DTA \\
\hline & $\mathrm{UFe}_{4} \mathrm{~B}+\mathrm{UFe}_{2} \rightarrow \mathrm{L}$ & & \\
\hline & - Ternary peritectic $\left(\mathrm{P}_{1}\right)$ & $1100-1170$ & DTA \\
\hline & $\mathrm{UFe}_{4} \mathrm{~B} \rightarrow \mathrm{L}+\mathrm{UFe}_{3} \mathrm{~B}_{2}+\mathrm{UFe}_{2}$ & & \\
\hline & - Boundary reaction $\left(\mathrm{L}_{4}\right)$ & & \\
\hline & $\mathrm{UFe}_{3} \mathrm{~B}_{2}+\mathrm{UFe}_{2} \rightarrow \mathrm{L}$ & & \\
\hline \multirow[t]{8}{*}{$\mathrm{U}: 3 \mathrm{Fe}: 2 \mathrm{~B}$} & - Ternary eutectic $\left(\mathrm{E}_{1}\right)$ & 980 & DTA \\
\hline & $\mathrm{UFe}_{4} \mathrm{~B}+\mathrm{UFe}_{2}+\gamma-\mathrm{Fe} \rightarrow \mathrm{L}$ & & \\
\hline & - Boundary reaction $\left(\mathrm{L}_{3}\right)$ & 1210 & DTA \\
\hline & $\mathrm{UFe}_{4} \mathrm{~B}+\mathrm{UFe}_{2} \rightarrow \mathrm{L}$ & & \\
\hline & - Boundary reaction $\left(\mathrm{L}_{4}\right)$ & & \\
\hline & $\mathrm{UFe}_{3} \mathrm{~B}_{2}+\mathrm{UFe}_{2} \rightarrow \mathrm{L}$ & & \\
\hline & - Melting of $\mathrm{UFe}_{3} \mathrm{~B}_{2}$ & 1250 & DTA \\
\hline & $\mathrm{UFe}_{3} \mathrm{~B}_{2} \rightarrow \mathrm{L}$ & & \\
\hline \multirow[t]{8}{*}{$\mathrm{U}: 2 \mathrm{Fe}: 3 \mathrm{~B}$} & - Ternary eutectic $\left(\mathrm{E}_{1}\right)$ & 980 & DTA \\
\hline & $\mathrm{UFe}_{4} \mathrm{~B}+\mathrm{UFe}_{2}+\gamma-\mathrm{Fe} \rightarrow \mathrm{L}$ & & \\
\hline & - Boundary reaction $\left(\mathrm{L}_{3}\right)$ & 1200 & DTA \\
\hline & $\mathrm{UFe}_{4} \mathrm{~B}+\mathrm{UFe}_{2} \rightarrow \mathrm{L}$ & & \\
\hline & - Boundary reaction $\left(\mathrm{L}_{4}\right)$ & & \\
\hline & $\mathrm{UFe}_{3} \mathrm{~B}_{2}+\mathrm{UFe}_{2} \rightarrow \mathrm{L}$ & & \\
\hline & - Boundary reaction $\left(\mathrm{L}_{3}\right)$ & 1200 & DTA \\
\hline & $\mathrm{UFe}_{4} \mathrm{~B} \rightarrow \mathrm{L}+\mathrm{UFe}_{3} \mathrm{~B}_{2}$ & & \\
\hline \multirow[t]{6}{*}{$2 \mathrm{U}: 8 \mathrm{Fe}: 3 \mathrm{~B}$} & - Ternary eutectic $\left(\mathrm{E}_{1}\right)$ & 980 & IF/DTA \\
\hline & $\mathrm{UFe}_{4} \mathrm{~B}+\mathrm{UFe}_{2}+\gamma-\mathrm{Fe} \rightarrow \mathrm{L}$ & & \\
\hline & - Melting of $\mathrm{UFe}_{3} \mathrm{~B}_{2}$ & 1240 & IF/DTA \\
\hline & $\mathrm{UFe}_{3} \mathrm{~B}_{2} \rightarrow \mathrm{L}$ & & \\
\hline & - Boundary reaction $\left(\mathrm{L}_{2}\right)$ & 1650 & IF \\
\hline & $\mathrm{UFe}_{3} \mathrm{~B}_{2} \rightarrow \mathrm{L}+\mathrm{UFeB}_{4}$ & & \\
\hline \multirow[t]{2}{*}{$\mathrm{U}: \mathrm{Fe}: 4 \mathrm{~B}$} & - Boundary reaction $\left(\mathrm{L}_{1}\right)$ & 1880 & IF \\
\hline & $\mathrm{UFeB}_{4} \rightarrow \mathrm{L}+\mathrm{UB}_{4}$ & & \\
\hline
\end{tabular}
inferred from the microstructures 


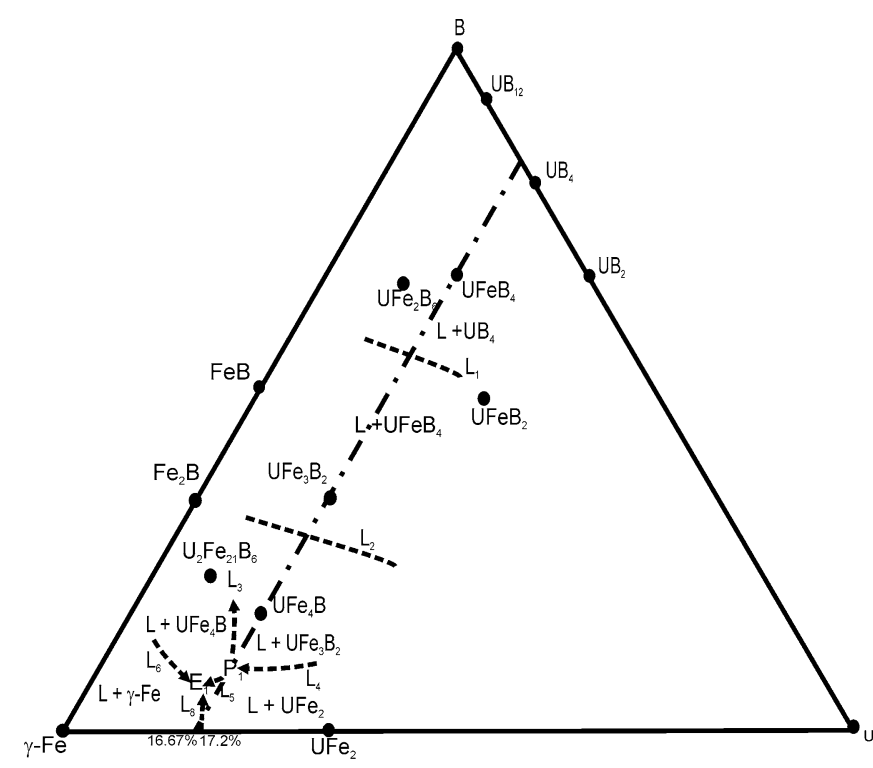

(a)

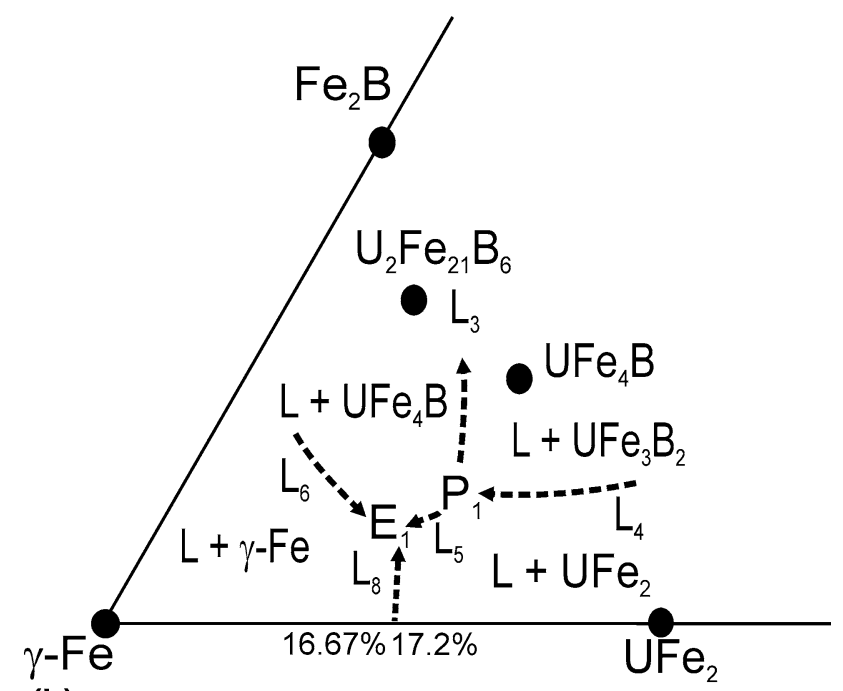

(b)

Fig. 7 (a) Liquidus projection across the U:(Fe.B) $=1: 5$ vertical section. (b) Magnified detail

$$
\begin{gathered}
\mathrm{L}+\mathrm{UB}_{4} \rightarrow \mathrm{UFeB}_{4} \\
\mathrm{~L}+\mathrm{UFeB}_{4} \rightarrow \mathrm{UFe}_{3} \mathrm{~B}_{2} \\
\mathrm{~L}+\mathrm{UFe}_{3} \mathrm{~B}_{2}+\mathrm{UFe}_{2} \rightarrow \mathrm{UFe}_{4} \mathrm{~B}
\end{gathered}
$$

showing that the formation temperature of the compounds decreases in the above order.

\subsection{Transition Temperatures}

Several exothermic transitions were detected with DTA by heating the as-cast alloys up to $1600{ }^{\circ} \mathrm{C}$ (Table 2). Heating curves obtained from an induction furnace equipped with a optical pyrometer revealed the same type of transformations up to $1600{ }^{\circ} \mathrm{C}$ and two additional thermal signals between $1600{ }^{\circ} \mathrm{C}$ and $2000{ }^{\circ} \mathrm{C}$ (also in Table 2). These results were interpreted on the basis of the microstructural constituents observed in the as-cast microstructure prior to heating: the lowest transformation temperature corresponds to the $\alpha-\mathrm{Fe} \rightarrow \gamma$-Fe allotropic transition (not always detected in the curves). This result was confirmed by HTXRD as can be observed in Fig. 6, where the peak corresponding to $\alpha$-Fe disappears at $930-940{ }^{\circ} \mathrm{C}$ and is replaced by the peak corresponding to $\gamma$-Fe. Martensite plates have been detected inside $\alpha$-Fe dendrites in the postmortem microstructure, indicating boron supersaturation. Solute diffusion and the lack of grain boundaries (especially triple joints ${ }^{[13]}$ ) are expected to have induced the large overheating detected for the $912{ }^{\circ} \mathrm{C}$ allotropic $\alpha$-Fe to $\gamma$-Fe transformation.

Considering the solidification paths described above, the next signal originates from the ternary eutectic $\left(E_{1}\right)$ melting, followed by melting of the $\mathrm{UFe}_{4} \mathrm{~B}$ and $\mathrm{UFe}_{2}$ eutectic mixture (not always detected in the curves), by the melting and peritectic decomposition of the $\mathrm{UFe}_{4} \mathrm{~B}$ compound (frequently associated with melting of $\mathrm{L}_{3}$ and $\mathrm{L}_{4}$ products, since these reactions converge at the ternary peritectic point), and, at higher temperatures, by the melting and peritectic decomposition of $\mathrm{UFe}_{3} \mathrm{~B}_{2}$, and by the melting and peritectic decomposition of $\mathrm{UFeB}_{4}$.

\subsection{Liquidus Projection and Isopleth at $U:(F e . B)=1: 5$ (16.67 at. \% U)}

The high cooling rate used to process the as-cast alloys hindered diffusion in the solid state and allowed the inference of a liquid path across the ternary diagram from the post-mortem microstructures. Based on the experimental results, a liquidus projection across the $\mathrm{U}:(\mathrm{Fe} . \mathrm{B})=1: 5$ line is proposed in Fig. 7. Alloys with 1:5 proportion presenting primary solidification above $\mathrm{L}_{1}$ (both in $\mathrm{B}$ content and temperature) show a deviation of the liquid composition to the left due to $\mathrm{UB}_{4}$ crystallization. As a result, these alloys exhibit phases situated on the left of the 1:5 line, such as $\mathrm{Fe}_{2} \mathrm{~B}$ (region $\mathrm{G}$ in Fig. $4 \mathrm{a}$ and $\mathrm{b}$ ). On the other hand, in alloys with $1: 5$ proportion presenting primary crystallization below $\mathrm{L}_{1}$ (through either $\mathrm{UFeB}_{4}$ or $\mathrm{UFe}_{3} \mathrm{~B}_{2}$ crystallization) the liquid composition is bound to follow the line (besides local composition variations), only to be departed when the congruent binary compound $\mathrm{UFe}_{2}$ forms after point $\mathrm{P}_{1}$. After this point the liquid follows the $\mathrm{L}_{5}$ eutectic valley and solidification ends at the $\mathrm{E}_{1}$ ternary eutectic, positioned to the left of the 1:5 line.

The vertical section at 16.67 at.\% $\mathrm{U}$ is given in Fig. 8 . The isopleth through 16.67 at.\% $\mathrm{U}$ intercepts two-fourphase reaction planes at $1100{ }^{\circ} \mathrm{C}\left(\mathrm{L}+\mathrm{UFe}_{3} \mathrm{~B}_{2}+\mathrm{UFe}_{2} \rightarrow\right.$ $\left.\mathrm{UFe}_{4} \mathrm{~B}\right)$ and $980{ }^{\circ} \mathrm{C}$, ( $\mathrm{L} \rightarrow \mathrm{UFe}_{2}+\mathrm{UFe}_{4} \mathrm{~B}+\gamma$-Fe). The isopleth position in the quaternary planes is defined in Fig. 9. The isopleth section crosses also four-three phase reaction lines $\mathrm{L}_{1}, \mathrm{~L}_{2}$ and $\mathrm{L}_{8}$ (the intersections are indicated 

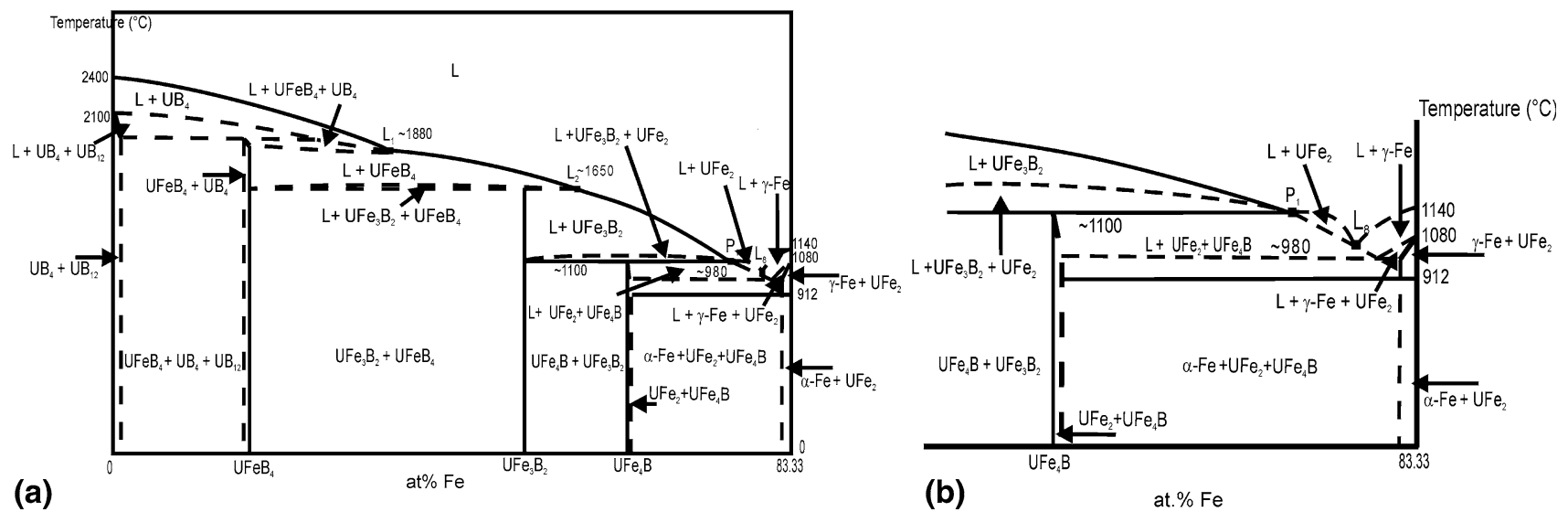

Fig. 8 (a) Isopleth at 16.67 at.\% U. The squares indicate intersections with boundary reactions in the liquidus projection. (b) Magnified detail of the 16.67 at.\% $\mathrm{U}$ isopleth proposed for the iron-rich corner. The lines position is approximate
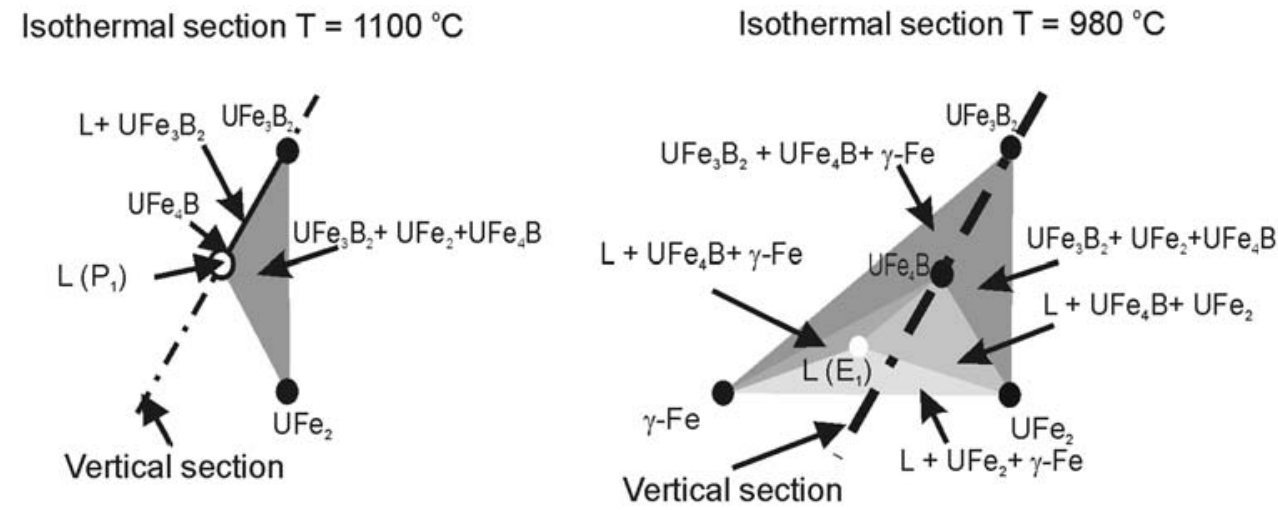

Fig. 9 Four-phase reaction planes at $1100{ }^{\circ} \mathrm{C}\left(\mathrm{P}_{1}\right)$ and at $980{ }^{\circ} \mathrm{C}\left(\mathrm{E}_{1}\right)$

by squares) in agreement with the liquidus projection in Fig. 7, where $\mathrm{L}_{8}$ represents the boundary reaction $\mathrm{L} \rightarrow$ $\gamma-\mathrm{Fe}+\mathrm{UFe}_{2}$ originating in the $\mathrm{Fe}-\mathrm{U}$ binary diagram.

\section{Conclusions}

Powder x-ray diffraction analysis, SEM observations complemented with EDS, DTA and heating curves of as-cast alloys demonstrated that the $\mathrm{UFeB}_{4}, \mathrm{UFe}_{3} \mathrm{~B}_{2}$ and $\mathrm{UFe}_{4} \mathrm{~B}$ compounds lying on the $\mathrm{U}:(\mathrm{Fe}, \mathrm{B})=1: 5$ line of the $\mathrm{B}-\mathrm{Fe}-\mathrm{U}$ system are formed by peritectic reactions. This justifies the complex microstructures and the presence of primary crystallization phases other than the expected compound for the stoichiometric compositions. A cascade of peritectic reactions was found to exist along the $\mathrm{U}:(\mathrm{Fe}, \mathrm{B})=1: 5$ line:

$$
\begin{gathered}
\mathrm{L}+\mathrm{UB}_{4} \rightarrow \mathrm{UFeB}_{4} \\
\mathrm{~L}+\mathrm{UFeB}_{4} \rightarrow \mathrm{UFe}_{3} \mathrm{~B}_{2} \\
\mathrm{~L}+\mathrm{UFe}_{3} \mathrm{~B}_{2}+\mathrm{UFe}_{2} \rightarrow \mathrm{UFe}_{4} \mathrm{~B}
\end{gathered}
$$

Therefore the solidification paths show that the formation temperatures of the compounds decrease in the above order. Solidification ends with the ternary eutectic of $\mathrm{UFe}_{2}+$ $\mathrm{UFe}_{4} \mathrm{~B}+\gamma$-Fe at $980{ }^{\circ} \mathrm{C}$. The isopleth diagram at 16.67 at. $\% \mathrm{U}$ proposed represents fundamental knowledge for the synthesis of pure compounds, necessary for physical properties characterization.

\section{Acknowledgments}

This work was partially supported by the exchange Program FCT/CMRS 2009-2010 and FCT, Portugal, under the contract no. PTDC/QUI/65369/2006.

\section{References}

1. P. Rogl, Ternary and Higher Order System of the Actinides and Boron, Handbook on the Physics and Chemistry of the Actinides, Vol 6, A.J. Freeman and C. Keller, Ed., Elsevier Science BV, 1991, p 75 
2. H. Ido, K. Konno, H. Ogata, K. Sugiyama, H. Hachino, M. Date, and K. Maki, Magnetic Study of $\mathrm{SmCo}_{5}, \mathrm{PrCo}_{5}$, $\mathrm{SmCo}_{4} \mathrm{~B}$ and $\mathrm{Sm}_{3} \mathrm{Co}_{11} \mathrm{~B}_{4}$ Under Pulse High Field, J. Appl. Phys., 1991, 70, p 6128-6130

3. C. Mazundar, R. Nagarajan, L.C. Gupta, B.D. Padalia, and R. Vijayarahavan, $\mathrm{SmNi}_{4} \mathrm{~B}$ : A Narrow Domain-Wall Ferromagnet, Appl. Phys. Lett., 2000, 6, p 895

4. S.A.M. Mentik, A. Drost, G.J. Nieuwenhuys, A.A. Menovsky, and J.A. Midosh, Anisotropic f-electron Magnetism in $\mathrm{UNi}_{4} \mathrm{~B}$, Phys. B Phys. Condens. Matter, 1994, 194, p 275-276

5. A.P. Gonçalves and H. Noël, Isothermal Section at $850{ }^{\circ} \mathrm{C}$ of the U-Fe-Al Ternary System, Intermetallics, 2004, 13, p 580585

6. H. Noël and A.P. Gonçalves, Isothermal Section at $750^{\circ} \mathrm{C}$ of the U-Fe-Sn Ternary System, Intermetallics, 2001, 9, p 473479

7. I.P. Valyovka and Yu.B. Kuzma, New Uranium Borides with the Structure of $\mathrm{YCrB}_{4}$ Type, Dopov. Akad. Nauk Ukr. RSR, A: Fiz.-Tekhn. Mat. Nauki, 1975, p 652
8. I.P. Valyovka and Yu.B. Kuzma, New Ternary Borides with Structures of $\mathrm{CeCo}_{3} \mathrm{~B}_{2}$ and $\mathrm{CeCo}_{4} \mathrm{~B}$ Type, Dopov. Akad. Nauk Ukr. RSR, A: Fiz.-Tekhn. Mat. Nauki, 1974, p 1029

9. M. Dias, P.A. Carvalho, O. Sologub, O. Tougait, H. Noël, C. Godart, E. Leroy, and A.P. Gonçalves, Isothermal Section at $950^{\circ} \mathrm{C}$ of the U-Fe-B Ternary System, Intermetallics, 2007, 15, p 413-418

10. M. Dias, P.A. Carvalho, O. Sologub, and A.P. Gonçalves, Crystal Structure of $\mathrm{UFe}_{2} \mathrm{~B}_{6}$ and $\mathrm{UFeB}_{2}$ Compounds, Intermetallics (to be submitted to publication)

11. G. Nozle and W. Kraus, Powder Cell for Windows, Version 2.2, Federal Institute for Materials Research and Testing, Berlin, 1999

12. C. Merlet, An Accurate Computer Correction Program for Quantitative Electron Probe Microanalysis, Microchim. Acta, 1994, 114/115, p 363-376

13. R. Angers and A. Couture, The Alpha Gamma Transformation Mechanisms in Iron Particles, Metall. Trans. A, 1987, 18, p 1151-1153 